\title{
Isolation and enzyme bioprospection of endophytic bacteria associated with plants of Brazilian mangrove ecosystem
}

\author{
Renata A Castro ${ }^{1}$, Maria Carolina Quecine ${ }^{2 *}$, Paulo T Lacava ${ }^{3}$, Bruna D Batista², Danice M Luvizotto², \\ Joelma Marcon ${ }^{2}$, Anderson Ferreira ${ }^{4}$, Itamar S Melo $^{5}$ and João L Azevedo ${ }^{1,2}$
}

\begin{abstract}
The mangrove ecosystem is a coastal tropical biome located in the transition zone between land and sea that is characterized by periodic flooding, which confers unique and specific environmental conditions on this biome. In these ecosystems, the vegetation is dominated by a particular group of plant species that provide a unique environment harboring diverse groups of microorganisms, including the endophytic microorganisms that are the focus of this study. Because of their intimate association with plants, endophytic microorganisms could be explored for biotechnologically significant products, such as enzymes, proteins, antibiotics and others. Here, we isolated endophytic microorganisms from two mangrove species, Rhizophora mangle and Avicennia nitida, that are found in streams in two mangrove systems in Bertioga and Cananéia, Brazil. Bacillus was the most frequently isolated genus, comprising $42 \%$ of the species isolated from Cananéia and 28\% of the species from Bertioga. However, other common endophytic genera such as Pantoea, Curtobacterium and Enterobacter were also found. After identifying the isolates, the bacterial communities were evaluated for enzyme production. Protease activity was observed in $75 \%$ of the isolates, while endoglucanase activity occurred in $62 \%$ of the isolates. Bacillus showed the highest activity rates for amylase and esterase and endoglucanase. To our knowledge, this is the first reported diversity analysis performed on endophytic bacteria obtained from the branches of mangrove trees and the first overview of the specific enzymes produced by different bacterial genera. This work contributes to our knowledge of the microorganisms and enzymes present in mangrove ecosystems.
\end{abstract}

Keywords: Mangrove; Endophytes; Bacteria; Biotechnological potential; Enzymes

\section{Background}

Mangroves are a tropical coastal biome that is located in the transition zone between the land and the sea where the vegetation is dominated by a particular group of plant species (Zhou et al. 2006). This ecosystem is characterized by periodic tidal flooding, making environmental factors such as salinity and nutrient availability highly variable and resulting in unique and specific environmental characteristics (Holguin et al. 2006). Thus, the mangrove ecosystem provides a distinct environment harboring diverse groups of microorganisms (Thatoi et al. 2013; Sivaramakrishnan et al. 2006). Although the mangrove

\footnotetext{
* Correspondence: mquecine@usp.br

2Department of Genetics, Escola Superior de Agricultura, "Luiz de Queiroz" (ESALQ), University of São Paulo, Piracicaba, SP, Brazil

Full list of author information is available at the end of the article
}

ecosystem is rich in microbial diversity, less than $5 \%$ of the species present have been described; in many cases, neither their ecological role nor their technological potential is known (Thatoi et al. 2013).

Various groups of bacteria are typically present in the mangrove ecosystem (Holguin et al. 2001) where they perform diverse activities including photosynthesis, nitrogen fixation, and methanogenesis (Das et al. 2006). Bacterial communities can be found living freely in mangrove sediments (Roy et al. 2002; Dias et al. 2009a, 2010) or as endophytes associated with the native flora (Garcias-Bonet et al. 2012; Janarthine et al. 2010; Liu et al. 2010; Feng et al. 2009).

Endophytes are microorganisms that live inside of plants without causing any harm to their hosts (Azevedo and Araújo 2007). Endophytic bacteria have been isolated from 
root nodules and the stems, leaves and fruits of a wide variety of plant species including citrus (Araujo et al. 2001), sugarcane (Gangwar and Kaur 2009), maize (Araujo et al. 2000), eucalyptus (Procopio 2009; Ferreira et al. 2008), soybean (Kuklinsky-Sobral et al. 2005; Assumpção et al. 2009), and strawberry (Dias et al. 2009a), among others. However, some endophytic communities remain unexplored in studies describing the bacterial communities from tropical native plants. Consequently, studies on the endophytic bacteria of plants from different ecosystems (mangroves, for example) offer a great opportunity to discover new compounds and resources with biotechnological potential that can be exploited (Sivaramakrishnan et al. 2006). Microorganisms from mangrove ecosystems contain useful enzymes, proteins, antibiotics and salt tolerant genes, all of which have biotechnological significance (Thatoi et al. 2013).

Microorganisms are important to enzymatic production processes because of their high production capability, low cost and susceptibility to genetic manipulation. There is strong biotechnological interest in microbial enzymes in several fields including food processing, detergent and textile manufacturing, agricultural and pharmaceutical research, medical therapy and molecular biology (Stamford et al. 1998; Carrim et al. 2006; Quecine et al. 2008 and 2011; Ferreira-Filho et al. 2012). Little is known about bacterial mangrove communities, but these microorganisms may have high biotechnological potential. Consequently, for the first time, the present work isolated and identified the endophytic bacteria taken from the branches of the two major species of mangrove plants, Rhizophora mangle (red mangrove) and Avicennia nitida (white mangrove), that are found in two different mangrove areas of São Paulo State, Brazil (Cananéia and Bertioga). Furthermore, this study investigated the potential of the bacterial isolates to produce enzymes with industrial interest, such as amylase, esterase, lipase, protease and endoglucanase.

\section{Results}

Bacterial isolation and molecular identification

Following isolation, bacterial abundance was estimated based on plant species and sampled area. The bacterial densities were very similar in all samples: approximately $10^{5} \mathrm{CFU} g$ tissue $^{-1}$ for both mangrove species analyzed ( $R$. mangle and A. nitida) and both sites (Bertioga and Cananéia).

The bacterial communities clearly differed in composition according to the mangrove species and locality. Bacterial isolates were classified into 14 genera. The isolates from Cananéia were grouped into 8 genera with a predominance of Bacillus sp. (42.1\%) followed by Enterobacter (10.5\%), Chryseobacterium (10.5\%), Xanthomonas (10.5\%), and others. The isolates from Bertioga were grouped into 9 genera with a predominance of Bacillus (28.6\%) followed by Curtobacterium (14.3\%), Alcaligenes
(14.3\%), Ochrobactrum (9.5\%), Novosphingobium (9.5\%), and others. Interestingly, Ochrobactrum and Microbacterium were only found in $R$. mangle branches, while Novosphingobium was isolated only from $A$. nitida branches (Table 1 ). Major isolates belongs to Bacilli class (35\%), followed by Gamaproteobacteria class (25\%). All isolates was classified at genus level, to avoid an incorrect classifications at specie level (Table 2).

The diversity parameters for each sample were very similar, as the comparative analysis of the Shannon diversity indices for $A$. nitida versus $R$. mangle and Bertioga versus Cananéia did not differ statistically according to $\mathrm{t}$-test analysis $(\mathrm{p}<0.05)$ (Table 3$)$.

Despite the similar values for the Shannon diversity indices, principal component analysis clearly demonstrated that the bacterial communities are specific according to locality and plant sample (Figure 1).

\section{Bacterial enzymatic activity}

The Enzymatic Index (EI) for all isolates was obtained following observation of their ability to produce at least 1 of

Table 1 Distribution of the genera of endophytic bacteria isolated from Brazilian mangrove forests

\begin{tabular}{|c|c|c|c|c|}
\hline \multirow[t]{3}{*}{ Genera } & \multicolumn{4}{|c|}{ Sample $^{a}$} \\
\hline & \multicolumn{2}{|c|}{ Cananéia } & \multicolumn{2}{|c|}{ Bertioga } \\
\hline & A. nitida & R. mangle & A. nitida & R. mangle \\
\hline Bacillus & 5 & 3 & 4 & 2 \\
\hline Enterobacter & - & 2 & - & - \\
\hline Pantoea & - & 1 & - & - \\
\hline Brevundimonas & 1 & - & - & - \\
\hline Microbacterium & 1 & - & 1 & - \\
\hline Chryseobacterium & 3 & - & - & - \\
\hline Novosphingobium & 1 & - & 1 & 1 \\
\hline Xanthomonas & 2 & - & - & - \\
\hline Erwinia & - & - & 1 & - \\
\hline Alcaligenes & - & - & 3 & - \\
\hline Ochrobactrum & - & - & - & 3 \\
\hline Curtobacterium & - & - & - & 3 \\
\hline Stenotrophomonas & - & - & - & 1 \\
\hline Sphingopyxis & - & - & 1 & - \\
\hline \multicolumn{5}{|c|}{ Diversity parameters ${ }^{\mathbf{b}}$} \\
\hline $\mathrm{S}$ & 6 & 3 & 6 & 5 \\
\hline $\mathrm{N}$ & 13 & 6 & 11 & 10 \\
\hline $\mathrm{D}$ & 2.35 & 1.12 & 2.08 & 2.17 \\
\hline$H^{\prime}(\operatorname{loge})$ & 1.74 & 1.00 & 1.59 & 1.69 \\
\hline 1-Lambda' & 0.84 & 0.72 & 0.84 & 0.89 \\
\hline
\end{tabular}

${ }^{a}$ Number of isolates from each plant and sample location.

${ }^{b}$ Diversity parameters: $\mathrm{S}$, total taxons; $\mathrm{N}$, total individuals; $\mathrm{D}$, species richness (Margalef); $\mathrm{H}^{\prime}$ (loge), Shannon; and $1-\lambda$, Simpson diversity indices for endophytic bacterial communities isolated from $A$. nitida and $R$. mangle branches sampled in Cananéia and Bertioga, Brazil. 
Table 2 Identification by partial sequencing of 16S rDNA of isolates from mangrove sediments

\begin{tabular}{|c|c|c|c|c|c|}
\hline Isolates & Class & Genus & Coverage & Identidade & Nearst Taxa \\
\hline MBR2.20 & Actinobacteria & Curtobacterium & 100 & 100 & Curtobacterium oceanosedimentum \\
\hline MBR2.21 & & & 100 & 100 & Curtobacterium oceanosedimentum \\
\hline MBR2.22 & & & 100 & 99 & Curtobacterium flaccumfaciens \\
\hline MCA2.54 & & Microbacterium & 100 & 100 & Microbacterium arborescens \\
\hline MBA2.52 & & & 100 & 99 & Microbacterium oleivorans \\
\hline MCR2.49 & Bacilli & Bacillus & 100 & 99 & Bacilus megaterium \\
\hline MCR2.51 & & & 100 & 100 & Bacillus altitudinis \\
\hline MCR2.56 & & & 100 & 94 & Bacillus vallismortis \\
\hline MCA2.42 & & & 100 & 99 & Bacillus safensis \\
\hline MCA2.51 & & & 100 & 100 & Bacillus pumilus \\
\hline MCA2.56 & & & 100 & 100 & Bacillus subtilis \\
\hline MCA2.53 & & & 100 & 100 & Bacillus subtilis \\
\hline MCA2.41 & & & 100 & 97 & Bacillus safensis \\
\hline MBR2.4 & & & 100 & 98 & Bacillus amyloliquefaciens \\
\hline MBR2.41 & & & 100 & 95 & Bacillus safensis \\
\hline MBA2.9 & & & 94 & 96 & Bacillus pumilus \\
\hline MBA2.33 & & & 100 & 100 & Bacillus safensis \\
\hline MBA2.4 & & & 100 & 99 & Bacillus pumilus \\
\hline MBA2.18 & & & 100 & 99 & Bacillus pumilus \\
\hline MCA2.12 & Alphaproteobacteria & Novosphingobium & 100 & 99 & Novosphingobium sp. \\
\hline MBR2.7 & & & 100 & 99 & Novosphingobium resinovorum \\
\hline MBA2.41 & & & 100 & 99 & Novosphingobium sp. \\
\hline MCA2.9 & & Brevundimonas & 100 & 99 & Brevundimonas vesiculares \\
\hline MBR2.46 & & Ochrobactrum & 100 & 100 & Ochrobactrum pseudogrignonense \\
\hline MBR2.39 & & & 100 & 100 & Ochrobactrum pseudogrignonense \\
\hline MBR2.33 & & & 100 & 99 & Ochrobactrum pseudogrignonense \\
\hline MBA2.44 & & Sphingopyxis & 100 & 100 & Sphingopyxis sp. \\
\hline MBA2.27 & Betaproteobacteria & Alcaligenes & 100 & 100 & Alcaligenes faecalis \\
\hline MBA2.16 & & & 100 & 99 & Alcaligenes faecalis \\
\hline MBA2.15 & & & 100 & 99 & Alcaligenes faecalis \\
\hline MCR2.37 & Gammaproteobacteria & Enterobacter & 100 & 98 & Enterobacter hormaechei \\
\hline MCR2.29 & & & 100 & 99 & Enterobacter sp. \\
\hline MCA2.21 & & Chryseobacterium & 100 & 99 & Chryseobacterium sp. \\
\hline MCA2.27 & & & 100 & 99 & Chryseobacterium sp. \\
\hline MCA2.23 & & & 100 & 100 & Chryseobacterium sp. \\
\hline MCA2.20 & & Xanthomonas & 100 & 100 & Xanthomonas campestris \\
\hline MCA2.39 & & & 100 & 99 & Xanthomonas sp. \\
\hline MCR2.33 & & Pantoea & 100 & 100 & Pantoea dispersa \\
\hline MBR2.29 & & Stenotrophomonas & 100 & 99 & Stenotrophomonas maltophilia \\
\hline MBA2.19 & & Erwinia & 100 & 98 & Erwinia tasmaniensis \\
\hline
\end{tabular}

5 evaluated enzymes. Amylolytic activity was observed in $45 \%$, esterasic activity in $17.5 \%$, lipolytic activity in $52.5 \%$, proteolytic activity in $75 \%$ and endocellulolytic activity in $62.5 \%$ of the tested isolates (Table 4 ).
Some isolates exhibited high enzymatic performance: Bacillus (MCR2.56) showed one of the highest amylase and esterasic activities with EI of 2.28 and 1.85, respectively. Six Bacillus isolates (MCR2.51, MCA2.42, MCA2.51, 
Table 3 Diversity t-test $(p<0.05)$ for bacterial communities isolated from $A$. nitida and $R$. mangle branches

\begin{tabular}{lcccc}
\hline \multicolumn{5}{c}{ Bertioga VS Cananeia } \\
& Shannon index & Variance & $\boldsymbol{P}$ & $\mathbf{T}$ \\
\hline Whole sample & 1.79 & 0.037 & & \\
Avicenia & 1.67 & 0.037 & & \\
Rizhophora & Avicenia vs Rizopphora & & \\
\hline & & & 0.644 & 0.464 (ns) \\
Whole sample & 1.87 & 0.031 & & \\
Bertioga & 1.64 & 0.051 & & \\
Cananeia & & & & \\
\hline
\end{tabular}

ns - non-significant.

The mangroves are located in Bertioga and Cananéia, SP, Brazil.

MBR2.4, MBA2.33, and MBA2.4) showed high endocellulolytic activities. The following genera also demonstrated high enzymatic productivity: Curtobacterium (MBR2.21), Ochrobactrum (MBR2.46), Microbacterium (MCA2.54), Brucella (MBR2.39), and Stenotrophomonas (MBR2.29) showed high endoglucanase activity; Erwinia sp. (MBA2.19) showed lipase activity; and Curtobacterium sp. (MBR2.20) showed protease and other activities.

\section{Discussion}

Currently, marine microorganisms are attracting increasing attention as a resource for new enzymes because the enzymes derived from marine microbes are relatively more stable and active than the corresponding enzymes derived from plants or animals (Lam 2006; Bull et al. 2000). Chen et al. (2012) isolated endophytic bacteria from 4 species of aquatic plants: Phragmites communis, Potamogeton crispus, Nymphaea tetragona and Najas marina. The isolated bacteria were classified into 12 genera in the Gammaproteobacteria, Bacilli, Alphaproteobacteria, Flavobacteria and Actinobacteria.However, studies focusing on the isolation and characterization of endophytic bacteria from native plant specimens from the Brazilian mangrove biome are rare. To our knowledge, the present work is the first report on the isolation, identification and enzymatic characterization of endophytic microorganisms from $R$. mangle and A. nitida in Brazil.

Bacillus was the most abundant genus isolated from all samples as described previously (Liu et al. Liu et al. 2010). Our data corroborate the results obtained by Ando et al. (2001) who isolated a large number of Bacillus sp. from mangrove sediments in Japan and reported the possible ability of these isolates to degrade organic pollutant compounds by fermentation. Various Bacillus sp. have also been isolated from several fish, mollusks, sediments and marine waters in Canada (Schulze et al. 2006). Ravikumar et al. (2010) isolated many endophytic bacteria from mangrove halophytic plants collected from the Pichavaram mangrove forest in India. Among the isolates, the authors identified two endophytes, B. thuringiensis (MB4) and B. pumilus (MB8), which were able to control many bacterial and fungal pathogens. Similarly, the endophytic strain B. amyloliquefaciens (RS261) is a biological agent isolated from the leaf of $R$. stylosa (Feng et al. 2009).

We found additional genera, such as Curtobacterium and Xanthomonas, colonizing specific plant species from specific localities. Interestingly, Microbacterium was isolated in both Bertioga and Cananéia, but only from $A$. nitida, suggesting host-specificity. Free-living Microbacterium has

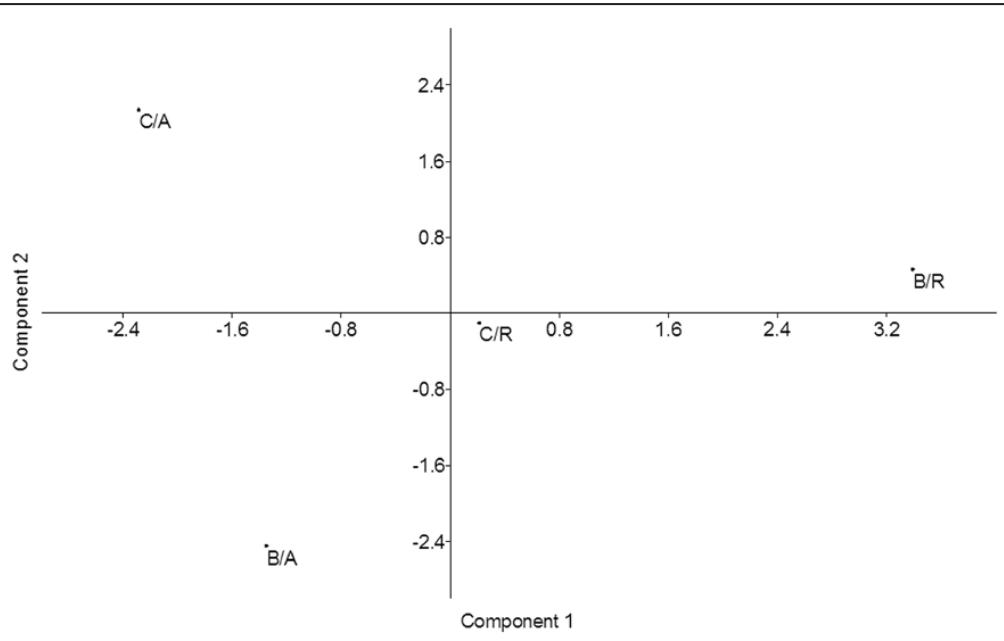

Figure 1 Principal component analysis (PCA) based on the molecular identification of bacterial isolates from Cananéia-Avicennia nitida (C/A), Cananéia-Rhizophora mangle (C/R), Bertioga-Avicennia nitida (B/A), and Bertioga-Rhizophora mangle (B/R). The values on the axes indicate the variance explained. 
Table 4 Enzymatic activity of the endophytic bacteria isolated from mangrove forests

\begin{tabular}{|c|c|c|c|c|c|c|}
\hline \multirow[t]{2}{*}{ Genus } & \multirow[t]{2}{*}{ Isolates $^{\mathrm{a}}$} & \multicolumn{5}{|c|}{ Enzymatic Index (EI) $^{\mathbf{b}}$} \\
\hline & & Amylase & Esterase & Lipase & Protease & Endoglucanase \\
\hline \multirow[t]{3}{*}{ Alcaligenes } & MBA2.15 & - & - & $2.23 \mathrm{f}$ & $1.43 \mathrm{e}$ & - \\
\hline & MBA2.27 & - & - & $4.25 c$ & - & $1.65 \mathrm{C}$ \\
\hline & (MBA2.16) & - & - & $1.73 \mathrm{~g}$ & $2.15 \mathrm{C}$ & $1.98 \mathrm{~b}$ \\
\hline \multirow[t]{14}{*}{ Bacillus } & MCA2.41 & - & - & $1.35 \mathrm{~g}$ & - & $1.60 \mathrm{C}$ \\
\hline & MCA2.42 & - & - & $2.80 \mathrm{e}$ & $2.48 \mathrm{~b}$ & $2.58 \mathrm{a}$ \\
\hline & MBA2.18 & - & - & $4.38 c$ & $1.23 \mathrm{f}$ & $2.08 \mathrm{~b}$ \\
\hline & MBA2.33 & $2.50 \mathrm{~b}$ & - & $4.80 \mathrm{c}$ & - & $2.73 \mathrm{a}$ \\
\hline & MBA2.4 & - & - & $2.55 \mathrm{f}$ & $1.75 d$ & $2.80 \mathrm{a}$ \\
\hline & MBA2.9 & $1.58 \mathrm{e}$ & - & - & - & - \\
\hline & MBR2.4 & $1.55 \mathrm{e}$ & - & - & - & $2.80 \mathrm{a}$ \\
\hline & MBR2.41 & $2.25 \mathrm{C}$ & $1.60 \mathrm{~b}$ & - & $1.33 \mathrm{f}$ & $1.60 \mathrm{c}$ \\
\hline & MCA2.51 & - & - & $3.13 d$ & $1.58 \mathrm{~d}$ & $2.75 \mathrm{a}$ \\
\hline & MCA2.53 & $2.75 \mathrm{a}$ & $1.63 \mathrm{~b}$ & - & $1.10 \mathrm{f}$ & $2.00 \mathrm{~b}$ \\
\hline & MCA2.56 & $2.28 \mathrm{~b}$ & - & $1.63 \mathrm{~g}$ & $1.23 \mathrm{f}$ & $1.90 \mathrm{~b}$ \\
\hline & MCR2.49 & $2.70 \mathrm{a}$ & $1.58 \mathrm{~b}$ & - & $1.65 d$ & - \\
\hline & MCR2.51 & - & - & $3.13 d$ & $1.58 d$ & $2.75 \mathrm{a}$ \\
\hline & MCR2.56 & $2.28 \mathrm{~b}$ & $1.85 \mathrm{a}$ & - & $1.23 \mathrm{f}$ & $2.23 \mathrm{~b}$ \\
\hline Brevundimonas & MCA2.9 & $1.80 \mathrm{~d}$ & - & - & $2.18 \mathrm{c}$ & - \\
\hline \multirow[t]{3}{*}{ Chryseobacterium } & MCA2.21 & $2.43 \mathrm{~b}$ & - & - & $1.58 \mathrm{~d}$ & - \\
\hline & MCA2.23 & - & - & $2.30 \mathrm{f}$ & - & - \\
\hline & MCA2.27 & $2.53 \mathrm{~b}$ & - & - & $1.53 \mathrm{e}$ & - \\
\hline \multirow[t]{3}{*}{ Curtobacterium } & MBR2.20 & - & - & - & $2.75 \mathrm{a}$ & - \\
\hline & MBR2.21 & - & - & - & $1.35 \mathrm{e}$ & $2.38 \mathrm{a}$ \\
\hline & MBR2.22) & - & $1.60 \mathrm{~b}$ & - & $1.05 \mathrm{~g}$ & $1.43 \mathrm{C}$ \\
\hline \multirow[t]{2}{*}{ Enterobacter } & MCR2.29) & - & - & - & $1.78 d$ & $1.73 \mathrm{C}$ \\
\hline & MCR2.37 & - & - & $2.50 \mathrm{f}$ & $1.35 \mathrm{e}$ & - \\
\hline Erwinia & MBA2.19 & $1.63 \mathrm{e}$ & $1.30 \mathrm{c}$ & $6.83 a$ & - & - \\
\hline \multirow[t]{2}{*}{ Microbacterium } & MBA2.52 & $1.73 \mathrm{~d}$ & - & - & $1.15 f$ & $2.13 b$ \\
\hline & MCA2.54 & - & - & $1.48 \mathrm{~g}$ & $1.75 \mathrm{~d}$ & $2.93 \mathrm{a}$ \\
\hline \multirow[t]{3}{*}{ Novosphingobium } & MBA2.41 & $1.80 \mathrm{~d}$ & - & $5.13 \mathrm{~b}$ & - & $2.13 b$ \\
\hline & MBR2.7 & $2.50 \mathrm{~b}$ & - & $3.48 d$ & $1.88 \mathrm{~d}$ & - \\
\hline & MCA2.12 & $2.78 \mathrm{a}$ & - & - & $1.65 d$ & - \\
\hline \multirow[t]{3}{*}{ Ochrobactrum } & MBR2.33 & - & - & - & $2.3 \mathrm{c}$ & $2.28 \mathrm{~b}$ \\
\hline & MBR2.39 & - & - & $3.08 d$ & - & $2.60 \mathrm{a}$ \\
\hline & MBR2.46 & - & - & $2.90 \mathrm{e}$ & - & $2.90 \mathrm{a}$ \\
\hline Pantoea & MCR2.33 & - & - & - & $1.68 d$ & $2.23 \mathrm{~b}$ \\
\hline Sphingopyxis & MBA2.44 & - & - & $4.75 b$ & $2.53 \mathrm{~b}$ & - \\
\hline Stenotrophomonas & MBR2.29 & $1.43 \mathrm{f}$ & - & $2.50 \mathrm{e}$ & $1.55 \mathrm{~d}$ & $2.63 a$ \\
\hline \multirow[t]{2}{*}{ Xanthomonas } & MCA2.20 & - & $1.38 c$ & - & $2.5 \mathrm{~b}$ & - \\
\hline & MCA2.39 & $1.15 \mathrm{~g}$ & - & - & $1.7 \mathrm{~d}$ & - \\
\hline
\end{tabular}

${ }^{a}$ Bacterial identification at the genus level with the name of the isolates in parentheses. The isolates were named according to host and the location of the samples: MCR, Mangrove Cananéia Rhizophora mangle; MCA, Mangrove Cananéia Avicennia nitida; MBR, Mangrove Bertioga Rhizophora mangle; MBA, Mangrove Bertioga Avicennia nitida.

${ }^{\mathrm{b}}$ The enzymatic index was measured by determining the ratio of degradation halo diameter/bacterial colony diameter. Values with the same letter within a column are not significantly $(p<0.05)$ different according to the Scott-Knott test. The results represent the means of four replicates for each isolate. 
been isolated from the same area from mangrove sediments (Dias et al. 2009a).

The diversity analysis clearly demonstrated that the evaluated parameters from each sample were similar; however, the bacterial communities are totally dependent on the host and the sampled site. Dias et al. (2010) assessed the bacterial diversity of mangrove sediments from São Paulo State by culture and also independent-culture methods. The authors observed that the location within the mangrove was determinant for all of the fractions of the community studied, which corroborates our data.

In further another point that should be explored is that mangrove microorganisms demonstrate a diverse range of enzymatic activities and are capable of catalyzing various biochemical reactions using novel enzymes (Thatoi et al. 2013; Dias et al. 2009b). Halophilic microorganisms in particular possess many hydrolytic enzymes and are capable of functioning under conditions that lead to precipitation or denaturation of most proteins (Ventosa and Nieto 1995).

As applied here, the enzymatic index was a fast and practical tool for selecting and comparing the enzyme production of different bacterial isolates. Values above 1.0 were indicative of enzyme secretion (Carrim et al. 2006). In the present study, all of the isolates showed the ability to produce at least one of five evaluated enzymes, proving their potential for industrial applications.

Dias et al. (2009b) evaluated the bacterial community from mangrove sediments in Brazil and found a predominance of organisms from the orders Vibrionales and Bacillales. These isolates were also able to produce diverse extracellular enzymes such as amylases, proteases, esterases and lipases, as found in the present work as well. The Bacillus spp. strains from mangrove sediments reached 5.53 and 5.06 amylase and protease enzymatic indexes, our Bacillus spp. strains reached 2.75 enzymatic indexes to both enzymes. However, the Bacillus sp. (MBA2.33) shows a lipase enzymatic index of 4.8, higher than of the best lipase producer Bacillus sp. 1A339 strain (lipase enzymatic index 3.88) from mangrove sediment (Dias et al. 2009b)

In a recent study, Khianngam et al. (2013) isolated and screened endophytic bacteria from mangrove plants in Thailand for the presence of hydrolytic enzymes. Twenty isolates showed activities associated with proteases, lipases, amylases or cellulases. The Rhf-2 strain, which was isolated from the fruit of Rhizophora mucronata, produced all of these enzymes; the strain was later identified as Bacillus safensis.

More than $50 \%$ of the isolates evaluated in the present work produced endoglucanase. Cellulases are commercially produced by several industries globally and are widely used in food, animal feed, fermentation, agriculture, pulp and paper, and textile applications (Kuhad et al. 2011).
Tabao and Moasalud (2010) evaluated the bioprospecting potential of the bacterial community found in mangroves in the Philippines, and the following four promising cellulase producing bacteria were identified: $B$. cereus, B. licheniformis, B. pumilus and Bacillus sp. Our study also identified many Bacillus sp. showing strong enzymatic production. Other isolated genera further demonstrated high productivity for proteases (Curtobacterium MBR2.20) and lipases (Erwinia sp. MBA2.19), suggesting their application as detergent additives (Jurado et al. 2007; Saeki et al. 2007).

\section{Conclusions}

Our work has improved the few information about the diversity of the endophytic bacterial communities from mangrove trees, suggesting a specific interaction between endophytes and mangrove host plants. Moreover, mangrove microorganisms demonstrated a diverse range of enzymatic activities that have been poorly explored biotechnologically. The isolates probably are capable of catalyzing various biochemical reactions using probable novel enzymes that should be further investigated in the future.

\section{Methods}

\section{Sample collection}

Branches from five randomly selected Rhizophora mangle and five Avicennia nitida trees located in Ber-

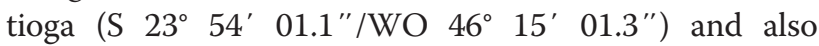
Cananéia (S 25 05' 87"/WO 47 57' 70"), São Paulo State, Brazil, were sampled for bacterial isolation. The samples were collected stored in plastic bags and taken to the laboratory for bacterial isolation.

\section{Bacterial isolation}

The tree samples were washed with water to remove adherent particles and were superficially disinfected according to Araújo et al. (2002). Then, the samples were cut into fragments, and roughly $1 \mathrm{~g}$ was triturated in the presence of $5 \mathrm{~mL}$ of PBS (Phosphate Buffered Saline) buffer, transferred to a $15 \mathrm{~mL}$ tube and shaken for 1 hour at $180 \mathrm{rpm}$. After obtaining the suspension of microorganisms, dilutions were made in PBS buffer, and aliquots of $100 \mu \mathrm{L}$ were inoculated onto 5\% Tryptic Soy Agar (TSA, Difco) medium supplemented with Benomyl $\left(50 \mu \mathrm{g} \mathrm{mL}^{-1}\right)$ to inhibit fungal growth. The plates were incubated at $28^{\circ} \mathrm{C}$ for $1-7$ days until growth was observed, upon which the number of colony-forming units (CFU) were counted and the population density estimated. Aliquots of $1.0 \mathrm{~mL}$ of the last wash water were also inoculated onto TSA medium to evaluate the effectiveness of the disinfection process, and only culture samples showing no growth were used.

Endophytic isolates were purified and inoculated into liquid 5\% Tryptic Soy Broth (TSB, Merck) medium 
supplemented with glycerol (15\% final concentration) and stored at $-80^{\circ} \mathrm{C}$ for future experiments.

\section{Molecular identification of bacterial isolates}

Bacterial isolates were identified by partial sequencing of $16 \mathrm{~S}$ rDNA. The $16 \mathrm{~S}$ rDNA was amplified directly from bacterial colonies grown on 10\% TSA medium using the primers R1387 (5'-CGGTGTGTACAAGGCCCGGGAA CG-3') and PO27F (5'-GAGAGTTTGATCCTGGCTC AG-3') (Heuer et al. 1997). The PCR reactions were performed in a $50 \mu \mathrm{L}$ volume containing $31.8 \mu \mathrm{l}$ deionized water, $5.0 \mu \mathrm{l}$ buffer, $7.5 \mu \mathrm{l} \mathrm{MgCl}$, $4.0 \mu \mathrm{l}$ dNTPs, $0.1 \mu \mathrm{l}$ of each primer, $0.5 \mathrm{U}$ Taq DNA polymerase and $1 \mu \mathrm{l}$ template DNA. The reaction conditions for the thermocycler (PTC 200, MJ Research) were as follows: initial denaturation for $4 \mathrm{~min}$ at $94^{\circ} \mathrm{C}$; followed by 35 cycles of $94^{\circ} \mathrm{C}$ for $30 \mathrm{~s}$, annealing for $1 \mathrm{~min}$ at $62.5^{\circ} \mathrm{C}$ and primer extension for $1 \mathrm{~min}$ at $72^{\circ} \mathrm{C}$; ending with a final extension for $7 \mathrm{~min}$ at $72^{\circ} \mathrm{C}$. The reaction products were analyzed on an agarose gel (1.2\%) together with a $1 \mathrm{~Kb}$ DNA molecular weight marker (Fermentas); the results were subsequently photographed.

The 16S rDNA PCR products (approximately $1400 \mathrm{bp}$ in size) were purified using the polyethylene glycol method of Lis (1980) and sequenced at the 'Instituto do Genoma Humano' (USP, São Paulo, Brazil). Sequencing was performed using the primer 1387R (Heuer et al. 1997).

The bacterial identification was performed comparing the sequences deposited in the following public banks: Ribosomal Database Project II (RDP) (www.rdp.cme. msu.edu) using the Classifier program with 95\% confidence (Wang et al. 2007) and GenBank from National Canter for Biotechnology Information-NCBI (www.ncbi. nlm.nih.gov) using, for this purpose, the BLASTn tool (Altschul et al. 1990). All of the bacterial sequences presented in this study were submitted to GenBank (accession numbers KF356428- KF356467).

\section{Enzymatic activity}

To forty molecular identified bacteria the production and the semi-quantitative measurement activity of the following enzymes was analyzed: amylase, esterase, lipase, cellulase and protease. To determine enzymatic activities, isolates were initially grown in $5 \%$ TSA for $24 \mathrm{~h}$ at $28^{\circ} \mathrm{C}$, after which $15 \mu \mathrm{l}$ aliquots $\left(\mathrm{OD}_{550 \mathrm{~nm}}=0.05\right.$, approximately $10^{8} \mathrm{CFU} / \mathrm{mL}$ ) dropped on specific media and incubated at $28^{\circ} \mathrm{C}$. The Enzymatic Index (EI) was measured after $72 \mathrm{~h}$ of incubation and was expressed as the ratio between the halo diameter and the bacterial colony diameter (Hankin et al. 1971; Hankin and Anagnostakis 1975).

The amylolytic activity was measured according to Hankin and Anagnostakis (1975). The isolates were inoculated onto 5\% TSA medium containing 1\% soluble starch. After bacterial growth, $5 \mathrm{~mL}$ of a $1 \%$ iodine solution was added to each plate, allowing the visualization of clear halos around the colonies.

The medium described by Sierra (1957) was used to evaluate the lipolytic activity. To sterilized culture medium, previously sterilized Tween 80 or Tween 20 was added to a final concentration of $1 \%(\mathrm{v} / \mathrm{v})$ to evaluate respectively the bacterial esterasic and lipase activity. The presence of halos was considered indicative of enzymatic activity.

To determine proteolytic activity, we used a culture medium containing skim milk according to Quecine (2010). The formation of a halo around the colony was considered indicative of proteolytic activity.

Finally, the cellulolytic activity of the isolates was evaluated according to Teather and Wood (1982). The isolates were grown on M9 medium (Sigma) containing $0.5 \%$ yeast extract and 1\% carboxymethylcellulose (CMC). After bacterial growth, $10 \mathrm{~mL}$ of Congo red dye (1\%) was added and the plates were washed with $\mathrm{NaCl}(5 \mathrm{M})$. The presence of a colorless halo around the colony was indicative of enzymatic activity.

\section{Data analysis}

The matrices generated from bacterial identification at the genus level were used in the molecular analysis described below. "Primer 6" (Plymouth Marine, Primer, United Kingdom) was used to obtain the different diversity indices: $S$, total profile; $\mathrm{N}$, profile value (band intensities); $\mathrm{d}$, species richness (Margalef); $H^{\prime}$ (loge), Shannon; and 1- $\lambda$, Simpson diversity.

Additionally, the t-test for the Shannon diversity index was realized using the PAST program (Hammer et al. 2001). Spatial distribution as determined by principal component analysis for the endophytic bacterial communities from $A$. nitida and $R$. mangle sampled from Bertioga and Cananéia was also determined using the PAST program. The axis values showed the percentage variance of each community.

The statistical analysis of enzymatic production was performed using the $\mathrm{R}$ program. A completely random design was used for all of the enzymatic assays. The EI values were measured using the ratio of halo diameter/bacterial diameter. All data were analyzed for significance $(\mathrm{p}<0.05)$ using the Scott-Knott test.

\section{Competing interests}

The authors declare that they have no competing interests.

\section{Authors' contributions}

The work presented here was carried out in collaboration between all authors. RAC, MCQ, PTL, DML, JM, AF defined the research theme. MCQ and JLA were primarily involved in searching, statistical analysis, compilation and verification and interpretation of data, and wrote the paper. ISM assisted with manuscript preparation. All authors have contributed to, seen and approved the manuscript. 


\section{Acknowledgments}

This work was supported by a grant from the Foundation for Research Assistance, São Paulo State (FAPESP), Brazil (Grant 2004/13910-6). We would like to thank FAPESP for the fellowships awarded to M.C.Q. (Proc. no. 10/ 50445-0), J.M. (Proc. no. 11/18740-5), and B.D.B. (Proc. no. 11/05204-8), and National Counsel of Technological and Scientific Development (CNPq) for the fellowships awarded to R.A.C., D.L.M. and A.F. We thank Dr. Fernando Pioto for his collaboration with the statistical analyses.

\section{Author details}

${ }^{1}$ Center for Nuclear Energy in Agriculture (CENA), University of São Paulo, Piracicaba, SP, Brazil. Department of Genetics, Escola Superior de Agricultura, "Luiz de Queiroz" (ESALQ), University of São Paulo, Piracicaba, SP, Brazil. ${ }^{3}$ Department of Morphology and Pathology, Center for Biological and Health Sciences, Federal University of São Carlos (UFSCar), São Carlos, SP, Brazil. ${ }^{4}$ Brazilian Agricultural Research Corporation - Embrapa Agrosilvopastoral, Sinop, MS, Brazil. ${ }^{5}$ Laboratory of Environmental Microbiology, CNPMA — Embrapa Environment, Jaguariúna, SP, Brazil.

Received: 18 March 2014 Accepted: 1 July 2014

Published: 28 July 2014

\section{References}

Altschul SF, Gish W, Miller W, Myers EW, Lipman DJ (1990) Basic local alignment search tool. J Mol Biol 215:403-410

Ando Y, Mitsugi N, Yano K, Karube I (2001) Isolation of a bacterium from mangrove soil for degradation of sea sludge. Appl Biochem Biotechnol 95:175-182

Araujo JM, Silva AC, Azevedo JL (2000) Isolation of endophytic actinomycetes from roots and leaves of maize (Zea mays L.). Braz Arch Biol Technol 43 : doi:10.1590/S1516-89132000000400016

Araújo WL, Maccheroni Junior W, Aguilar-Vildoso Cl, Barroso PAV, Saridakis HO, Azevedo JL (2001) Variability and interactions between endophytic bacteria and fungi isolated from leaf tissues of citrus rootstocks. Can J Microbiol 47:229-236, doi:10.1139/cjm-47-3-229

Araújo LW, Lima AOS, Azevedo JL, Marconi J, Sobral JK, Lacava PT (2002) Manual: isolamento de microrganismos endofíticos. USP, Piracicaba, SP

Assumpção LC, Lacava PT, Dias ACF, Azevedo JL, Menten JOM (2009) Diversidade e potencial biotecnológico da comunidade bacteriana endofítica de sementes de soja. Pesq Agropec Bras 44:503-510, doi:10.1590/S0100$204 \times 2009000500010$

Azevedo JL, Araújo WL (2007) Diversity and applications of endophytic fungi isolated from tropical plants. In: Ganguli BN, Desh-Mukh SK (eds) Fungi: multifaceted microbes. India \& CRC Press, Boca Raton, USA, pp 189-207

Bull AT, Ward AC, Goodfellow M (2000) Search and discovery strategies for biotechnology: The paradigm shift. Microbiol Mol Biol Rev 64:573-606

Carrim AJl, Barbosa EC, Vieira JDG (2006) Enzymatic activity of endophytic bacterial isolates of Jacaranda decurrens Cham. (Carobinha-do-campo). Braz Arch Biol Technol 49:353-359, doi:10.1590/S1516-89132006000400001

Chen WM, Tang YQ, Mori K, Wu XL (2012) Distribution of culturable endophytic bacteria in aquatic plants and their potential for bioremediation in polluted waters. Aquat Biol 15:99-110, doi:10.3354/ab004422

Das S, Lyla PS, Khan SA (2006) Spatial variation of aerobic culturable heterotrophic bacterial population in sediment of the Continental slope of western Bay of Bengal. Ind J Mar Sci 36:51-58

Dias ACF, Costa FEC, Andreote FD, Lacava PT, Teixeira MA, Assumpção LC, Araújo WL, Azevedo JL, Melo IS (2009a) Isolation of micropropagated strawberry endophytic bacteria and assessment of their potential for plant growth promotion. World J Microbiol Biotechnol 25:189-195, doi:10.1007/s11274-008-9878-0

Dias ACF, Andreote FD, Dini-Andreote F, Lacava PT, Sá ALB, Melo IS, Azevedo JL, Araújo WL (2009b) Diversity and biotechnological potential of culturable bacteria from Brazilian mangrove sediment. World J Microbiol Biotechnol 25:1305-1311, doi:10.1007/s11274-009-0013-7

Dias ACF, Andreote FD, Rigonato J, Fiore MF, Melo IS, Araújo WL (2010) The bacterial diversity in a Brazilian non-disturbed mangrove sediment. Antonie van Leeuwenhoek 98:541-551, doi:10.1007/s10482-010-9471

Feng L, Ou X, He H, Hu H, Zhang X (2009) Control of Capsicum phytophthora blight by endophytic bacteria RS261 from mangrove. Acta Phytopathol Sinica 39:333-336

Ferreira Filho AS, Quecine MC, Bogas AC, Rossetto PB, Lima AOS, Lacava PT, Azevedo JL, Araújo WL (2012) Endophytic Methylobacterium extorquens expresses a heterologous b-1,4-endoglucanase A (EglA) in Catharanthus roseus seedlings, a model host plant for Xylella fastidiosa. World J Microbiol Biotechnol 28:1475-148, doi:10.1007/s11274-011-0949-2

Ferreira A, Quecine MC, Lacava PT, Oda S et al (2008) Diversity of endophytic bacteria from Eucalyptus species seeds and colonization of seedlings by Pantoea agglomerans. FEMS Microbiol Lett 287:8-14, doi:10.1111/ j.1574-6968.2008.01258.x

Gangwar M, Kaur G (2009) Isolation and characterization of endophytic bacteria from endorhizosphere of sugarcane and ryegrass. Internet J Microbiol 7: doi:10.5580/181d

Garcias-Bonet NG, Arrieta JM, Santana CN, Duarte CM, Marbá N (2012) Endophytic bacterial community of a Mediterranean marine angiosperm (Posidonia oceanica). Front Microbiol 3:342, doi:10.3389/fmicb.2012.00342

Hammer $\varnothing$, Harper DAT, Ryan PD (2001) PAST: Paleontological Statistics Software Package for Education and Data Analysis. Palaeo Electron, http://palaeo-electronica.org/2001_1/past/issue1_01.htm (accessed 15 jun 2013)

Hankin L, Anagnostakis SL (1975) The use of solid media for detection of enzyme production by fungi. Mycologia 67:597-607

Hankin L, Zucker M, Sands DC (1971) Improved solid medium for the detection and enumeration of pectolytic bacteria. Appl Microbiol 22:205-209

Heuer H, Krsek M, Baker P, Smalla K, Wellington EMH (1997) Analysis of actinomycete communities by specific amplification of genes encoding $16 \mathrm{~S}$ rDNA and gel-electrophoretic separation in denaturing gradients. Appl Environ Microbiol 63:3233-3241

Holguin G, Vazquez P, Bashan Y (2001) The role of sediment microorganisms in the productivity, conservation, and rehabilitation of mangrove ecosystems: an overview. Biol Fertil Soils 33:265-278, doi:10.1007/s003740000319

Holguin G, Zamorano PG, De-Bashan LE, Mendoza R, Amador E, Bashan Y (2006) Mangrove health in an arid environment encroached by urban development a case study. Sci Total Environ 363:260-274, doi:10.1016/j.scitotenv.2005.05.026

Janarthine RSS, Eganathan P, Balasubramanian T (2010) Plant growth promoting of endophytic Bacillus cereus isolated from the pneumatophores of Avicennia marina. Int J Curr Res 5:9-13, doi:10.1155/2012/532060

Jurado E, Bravo V, Luzon G, Fernandez-Serrano M, Garcia-Roman M, Altmajer-Vaz D, Vicaria JM (2007) Hard-surface cleaning using lipases: enzyme-surfactant interactions and washing tests. J Surfact Deterg 10:61-70, doi:10.1007/ s11743-006-1009-z

Khianngam S, Techakriengkrai T, Raksasiri BV, Kanjanamaneesathian M, Tanasupawat S (2013) Isolation and screening of endophytic bacteria for hydrolytic enzymes from plant in mangrove forest at Pranburi, Prachuap Khiri Khan, Thailand. In: Schneider C, Leifert C, Feldmann F (eds) Endophytes for plant protection: the state of the art. Proc 5th Int Symp Plant Protect Plant Health Europe. Deutsche Phytomedizinische Gesellschaft, Berlin, pp 279-284

Kuhad RC, Gupta R, Singh A (2011) Microbial cellulases and their industrial applications. Enzyme Res 2011:280696, doi:10.4061/2011/280696

Kuklinsky-Sobral J, Araujo WL, Mendes R, Pizzirani-Kleiner AA, Azevedo JL (2005) Isolation and characterization of endophytic bacteria from soybean (Glycine max) grown in soil treated with glyphosate herbicide. Plant Soil 273:91-99, doi:10.1007/s11104-004-6894-1

Lam SK (2006) Discovery of novel metabolites from marine actinomycetes. Curr Opin Microbiol 9:245-251, doi:10.1016/j.mib.2006.03.004

Lis JT (1980) Fractionation of DNA fragments by polyethylene glycol induced precipitation. Methods Enzymol 65:347-353

Liu Y-L, Chen G, Chen X-C (2010) Isolation of endophyte bacteria from mangrove and screening of antagonistic strains against dematiaceous fungi. China Trop Medic 01, http://en.cnki.com.cn/Article_en/CJFDTotal-RDYX201001010.htm (accessed 15 jun 2013)

Procópio REL, Araújo WL, Maccheroni W Jr, Azevedo JL (2009) Characterization of an endophytic bacterial community associated with Eucalyptus spp. Genet Mol Res 8:1408-1422, doi:10.4238/vol8-4gmr691

Quecine MC (2010) Aspectos biotecnológicos da interação entre bactérias e cana-de-açúcar (Saccharum sp. L.). Thesis. Escola Superior de Agricultura "Luiz de Queiroz", University of São Paulo

Quecine MC, Araújo WL, Marcon J, Gai CS, Azevedo JL, Pizzirani-Kleiner AA (2008) Chitinolytic activity of endophytic Streptomyces and potential for biocontrol. Lett Appl Microbiol 47(6):486-491, doi:10.1111/j.1472-765X.2008.02428.x

Quecine MC, Lacava PT, Magro SR, Parra JRP, Araújo WL, Azevedo JL, Pizzirani Kleiner AA (2011) Partial characterization of chitinolytic extract from endophytic Streptomyces sp. and its effects on the boll weevil. J Agri Sci Technol 5:420-427 
Ravikumar S, Inbaneson SJ, Sengottuvel R, Ramu A (2010) Assessment of endophytic bacterial diversity among mangrove plants and their antibacterial activity against bacterial pathogens. Ann Biol Res 1:240-247

Roy S, Hens D, Biswas D, Kumar R (2002) Survey of petroleum-degrading bacteria in coastal waters of Sunderban biosphere reserve. World J Microbiol Biotechnol 18:575-581

Saeki K, Kobayashi T, Ito S (2007) Detergent alkaline proteases: enzymatic properties, genes, and crystal structures. J Biosci Bioeng 103:501-508

Schulze AD, Alabi AO, Sheldrake ART, Miller KM (2006) Bacterial diversity in a marine hatchery: balance between pathogenic and potentially probiotic bacterial strains. Aquaculture 256:50-73, doi:10.1016/j.aquaculture.2006.02.008

Sierra GA (1957) A simple method for the detection os lypoytic activity of microorganisms and some observations on the influence of the contact between cells and fatty substracts. Antonine van Leeuwenhoeck 28:15-22

Sivaramakrishnan S, Gangadharan D, Nampoothiri KM, Soccol CR, Pandey A (2006) a-Amylases from microbial sources-an overview on recent developments. Food Technol Biotechnol 44:173-184

Stamford TLM, Araujo JM, Stamford NP (1998) Atividade enzimática de microrganismos isolados do jacatupé (Pachyrhizus erosus L. Urban). Ciênc Tecnol Aliment 18:382-385, doi:10.1590/S0101-20611998000400004

Tabao NC, Moasalud RG (2010) Characterisation and identification of high cellulose-producing bacterial strains from Philippine mangroves. Philipp J System Biol 4:13-20, doi:10.3860/pjsb.v4i0.1562

Teather RM, Wood PJ (1982) Use of congo red-poliysaccharide interactions in enumeration and characterization of cellulolytic bacteria from bovine rumen. Appl Environ Microbiol 43:777-780

Thatoi H, Behera BC, Mishra RR, Dutta SK (2013) Biodiversity and biotechnological potential of microorganisms from mangrove ecosystems: a review. Ann Microbiol 63:1-19, doi:10.1007/s13213-012-0442-7

Ventosa A, Nieto JJ (1995) Biotechnological applications and potentialities of halophilic microorganisms. World J Microbiol Biotechnol 11:85-94

Wang Q, Garrity GM, Tiedje JM, Cole JR (2007) Naive Bayesian classifier for rapid assignment of rRNA sequences into the new bacterial taxonomy. Appl Environ Microbiol 73:5261-5267, doi:10.1128/AEM.00062-0

Zhou HW, Guo CL, Wong YS, Tam NFY (2006) Genetic diversity of dioxygenase genes in polycyclic aromatic hydrocarbon-degrading bacteria isolated from mangrove sediments. FEMS Microbiol Lett 262:148-157, doi:10.1111/ j.1574-6968.2006.00379.x

doi:10.1186/2193-1801-3-382

Cite this article as: Castro et al:: Isolation and enzyme bioprospection of endophytic bacteria associated with plants of Brazilian mangrove ecosystem. SpringerPlus 2014 3:382.

\section{Submit your manuscript to a SpringerOpen ${ }^{\circ}$ journal and benefit from:}

- Convenient online submission

- Rigorous peer review

- Immediate publication on acceptance

- Open access: articles freely available online

- High visibility within the field

- Retaining the copyright to your article

Submit your next manuscript at $\gg$ springeropen.com 